\title{
Reproductive assurance through self-fertilization does not vary with population size in the alien invasive plant Datura stramonium
}

\author{
Mark van Kleunen, Markus Fischer and Steven D. Johnson \\ M. van Kleunen (vkleunen@ips.unibe.ch) and S. D. Johnson, Centre for Invasion Biology, School of Biological and Conservation \\ Sciences, Univ. of KwaZulu-Natal, P. Bag X01 Scottsville, Pietermaritzburg 3209, South Africa.-M. Fischer and present address for \\ MvK: Inst. of Plant Sciences, Univ. of Bern, CH-3013 Bern, Switzerland. MF also at: Inst. for Biochemistry and Biology, Univ. of \\ Potsdam, Maulbeerallee 1, DE-14469 Potsdam, Germany.
}

\begin{abstract}
Autonomous self-fertilization is suggested to be associated with invasiveness in plants because it offers reproductive assurance when there is a shortage of suitable mates or pollinators. Given that shortages of mates and pollinators are a common cause of Allee effects in small plant populations, we predict that the benefits of self-fertilization in terms of reproductive assurance should be greatest in small populations. We tested this idea for the invasive herb Datura stramonium, a self-fertilizing species which is also cross-pollinated to some extent by insects (mainly hawkmoths and honeybees). During two consecutive years, we studied 20 and 55 populations, respectively, of different sizes. Untreated flowers of D. stramonium showed high levels of fruit and seed set in all populations studied. Although, fruit and seed set were generally reduced by about $90 \%$ in flowers in which selffertilization was prevented through emasculation, this effect did not vary according to population size. By using a natural color (anthocyanin) dimorphism in 12 populations, we showed that the average outcrossing rate was low $(1.3 \%)$ and that there was no relationship between outcrossing rate and population size. Pollen removal from flowers also did not vary according to population size, suggesting that the pollinator visitation rate is not lower in small populations. However, decreasing deviations of observed from expected fruit set with population size imply that small populations may have an increased chance of extinction due to demographic stochasticity. Overall, our results suggest that reproductive assurance through self-fertilization in invasive plants may be important for all stages of population establishment, and not just in the founder population.
\end{abstract}

The Allee effect, i.e. the negative effect of a low number or density of conspecifics in a population on individual fitness (Stephens et al. 1999) may have important consequences for the persistence and spread of populations. The phenomenon is well-documented among rare and endangered species that often occur in small remnant populations (Oostermeijer et al. 1994, Fischer and Matthies 1998, Fischer et al. 2000, Ward and Johnson 2005). However, much less is known about Allee effects in small founding populations of invasive species (Taylor and Hastings 2005, Drake and Lodge 2006, Ouborg et al. 2006). It could be hypothesized that alien species will be unusually resistant to Allee effects both during the establishment phase and at the leading edge of the invasion (van Kleunen and Johnson 2005).
The most important general implication of an Allee effect is that it creates a critical population size threshold above which the population will grow to its carrying capacity and below which it will go extinct (Liebhold and Bascompte 2003). As a consequence, Allee effects could prevent establishment of alien species (Leung et al. 2004, Taylor et al. 2004, Tobin et al. 2007) and slow down the spread of an invasive species (Lewis and Kareiva 1993, Veit and Lewis 1996, Drake and Lodge 2006, Tobin et al. 2007). Moreover, the existence of such a threshold due to Allee effects may have important implications for management of invasive species (Taylor and Hastings 2004) because for their eradication it might be sufficient to reduce the number of individuals below the critical population size 
threshold rather than remove each individual (Liebhold and Bascompte 2003). So far, however, only few studies have empirically tested for Allee effects in invasive plants (Cappuccino 2004, Davis et al. 2004a, 2004b, van Kleunen and Johnson 2005) and as a consequence it is not yet known how pervasive Allee effects are in invasive organisms (Taylor and Hastings 2005, Drake and Lodge 2006).

The two most likely ecological causes of Allee effects in sexually reproducing invasive plants are a decreased number of suitable mates and pollinator limitation in small populations (Silander 1978, Boukal and Berec 2002, Ward and Johnson 2005). This is especially true when combined with self-incompatibility. Plants that possess traits that enable them to overcome or mitigate partner or pollinator limitation may be more invasive outside their native range than species without such traits. One hypothesis, which is commonly referred to as Baker's Law, poses that self-compatibility, particularly when associated with capacity for autonomous seed production, would allow plants to circumvent partner or pollen limitation in small founding populations (Baker 1955, 1974, Stebbins 1957). Indeed, selfcompatible species are often more invasive than self-incompatible ones (Rambuda and Johnson 2004 , van Kleunen and Johnson 2007), which indicates that a plant's breeding system is an important determinant of its potential invasiveness.

It is not known, however, whether self-compatible invasive species depend on self-compatibility only during initial population establishment or also when populations are large. Indications for this could be obtained by assessment of actual outcrossing rates in small and large populations, as has been done for some endangered species (Raijmann et al. 1994). However, a critical test of this would be to compare the extent of reproductive assurance from self-fertilization between small and large populations. This can be done by emasculating the flowers of facultatively autogamous plants in both large and small populations. Given that pollen limitation is often more severe in small populations (Ågren 1996, Ward and Johnson 2005), it could be predicted that in small populations experimentally emasculated flowers would suffer from lower seedproduction, while non-emasculated flowers would not suffer from this limitation. Such tests have rarely been done, and only for native species (Eckert and Schaefer 1998).

Stochastic dynamics due to variability in the environment (environmental stochasticity) and mortality and reproduction rates between individuals in the population (demographic stochasticity) could, in theory, overrule the Allee effect and cause further spread of the population when it is below the critical population size threshold or population extinction when it is above the critical population size threshold (Liebhold and
Bascompte 2003). While environmental stochasticity is likely to affect both small and large populations equally, demographic stochasticity is likely to play a more important role in small populations than in large populations (Lande 1993, Kéry et al. 2003, Liebhold and Bascompte 2003). Therefore, it is important to test not only the effect of population size on plant fitness components but also on variation in these components.

We used the self-compatible annual herb Datura stramonium in its invasive range in South Africa to address these issues because its populations vary largely in size, the flower buds are easy to emasculate, and it possesses an anthocyanin dimorphism that can be used to estimate outcrossing rates (Motten and Antonovics 1992). During two consecutive years, in which we used 20 and 55 populations, respectively, we tested the effects of population size of $D$. stramonium on pollen removal as a proxy of pollinator visitation rate, reproductive assurance by autonomous selfing, seed production, germination and outcrossing rate. Specific questions posed in this study were: (1) does flower visitation by potential pollinators increase with population size? (2) Does seed production per fruit and seed quality increase with population size? (3) Does the species depend on reproductive assurance through autonomous selfing, and does the importance of autonomous selfing decline with population size? (4) Does the outcrossing rate increase with population size? (5) Do the effects of stochastic dynamics on visitation rates and fruit production decline with population size?

\section{Material and methods}

\section{Study species}

The common thorn-apple Datura stramonium (Solanaceae) is an annual plant that is invasive in almost all temperate and tropical regions of the world. Its region of origin is not known with certainty but is most likely in Central or South America (Circosta et al. 1985, Jiao et al. 2002). In South Africa, the oldest herbarium specimen dates from 1886 (information from the National Herbarium Pretoria Computerised Information Service, South Africa), indicating that the species was introduced here at least a century ago. Datura stramonium is widespread throughout South Africa, where it mainly inhabits recently disturbed sites in agricultural fields, industrial areas and road sides (Henderson 2001).

Flowering plants of $D$. stramonium can range in height from $10 \mathrm{~cm}$ to $2 \mathrm{~m}$. Large $(7-10 \mathrm{~cm}$ long) trumpet-shaped flowers are produced singly from axillary meristems. Flowers are either purple or white due to the presence and absence of anthocyanins, 
respectively. Anthocyanin production can also be determined in seedlings, as purple-flowered plants have red hypocotyls and stems in contrast to the green ones of the white-flowered plants (Motten and Antonovics 1992). The color dimorphism is coded for by a single locus and is inherited in simple Mendelian fashion (Blakeslee and Avery 1917). The anthocyanin allele coding for purple flowers and red hypocotyls and stems is dominant over the one coding for white flowers and green hypocotyls and stems. Therefore each red seedling of a white-flowered mother plant has to be the heterozygous consequence of outcrossing. Each flower has one pistil surrounded by five stamens, and flowers open at the end of the day and wilt the following morning.

The shape, strong scent and high nectar content of the flowers suggest that hawkmoths are likely to be the main pollinators (Motten and Antonovics 1992). Although we have observed hawkmoths visiting flowers of D. stramonium, pollen-collecting honeybees (Apis mellifera) also frequently visit unfurling flowers during the late afternoons (van Kleunen pers. obs.). The mean $\pm S E$ number of pollen grains of $D$. stramonium on honeybees, excluding their corbicula (pollen baskets), that we caught in populations of $D$. stramonium was $193 \pm 70(\mathrm{n}=9)$, indicating that honeybees might act as pollinators. Datura stramonium is highly selfcompatible and can produce seeds by autogamy in the absence of pollinators (Blakeslee and Avery 1917, Motten and Antonovics 1992, van Kleunen and Johnson unpubl.). The fruits are thorny capsules of up to $4 \mathrm{~cm}$ long and may contain up to 650 seeds.

\section{Study populations}

For the experiments described below, we used a total of 20 populations in the first year (Appendix 1) and increased this to a total of 55 populations in the second year (Appendix 2) to increase statistical power. Six populations were used in both years (Appendix 2). Populations were haphazardly selected to represent the widest size range of populations that we could find in our study area. All populations were within $100 \mathrm{~km}$ distance from Pietermaritzburg $\left(29^{\circ} 38^{\prime} \mathrm{S}\right.$, $\left.30^{\circ} 24^{\prime} \mathrm{E}\right)$, South Africa, and separated from each other by at least $200 \mathrm{~m}$. As an estimate of population size, we counted the number of flowering plants at the beginning and the end of the experimental periods, and calculated the geometric mean (Appendix 1,2). Population sizes ranged from 1 to 406 and 1 to 800 flowering plants in the first and second year, respectively.

\section{Experiments}

Pollen removal in relation to population size

Observations revealed that honeybees often actively collected most pollen from the anthers of D. stramonium by late afternoon. Visitation by hawkmoths may also result in pollen removal but probably to a lesser extent because they do not actively collect pollen. To test for differences in insect visitation between small and large populations of $D$. stramonium, we estimated pollen removal from anthers in 38 of the 55 populations in the second year (Appendix 2). On 13 January 2005, we collected one anther from a flower that had wilted but had been open during the previous night and one control anther from an unopened flower on the same plant in each of the 38 populations. Anthers were kept separately in micro-centrifuge tubes. To release all pollen from the anthers, we squashed them with a small pestle in $500 \mu \mathrm{l} 70 \%$ ethanol. To estimate the number of pollen grains per anther, we mixed the pollen solution by using a vortex, put $25 \mu \mathrm{l}$ on a microscope slide, stained the pollen by adding one drop of $1 \%$ analine blue in lactophenol, and counted the number of pollen grains by using a light microscope. We calculated the pollen removal rate per plant by dividing the number of pollen grains in the wilted flower by the number of pollen grains in the unopened control flower.

Our estimates of pollen removal may also include loss of pollen from anthers due to natural pollen shedding. To estimate this, we performed a small trial experiment in which we compared numbers of pollen grains in anthers of 13 wilted open-pollinated flowers, 13 wilted flowers from which insects had been excluded with nylon mesh bags and 13 unopened control flowers. The comparison between unopened control flowers and wilted bagged flowers revealed that natural pollen shedding accounted for $65.6 \%$ of all pollen loss. This percentage was still considerably lower than the $99.4 \%$ pollen loss when insects could remove pollen. This shows that visitation by insects can account for a considerable proportion of pollen removal, and that differences therein most likely indicate differences in visitation rates.

Reproductive assurance in relation to population size To test for changes in the importance of autonomous self-fertilization for reproductive assurance with population size of $D$. stramonium, we performed an emasculation experiment in 19 of the 20 populations in 2003 (Appendix 1) and in 54 of the 55 populations in 2004 (Appendix 2). From 30 November to 23 December 2003, we visited each of the 19 populations four to five times and on each visit, depending on the size of the population (Appendix 1), we emasculated 
one flower on each of $1-8$ plants by using a pair of tweezers. Because plants frequently have $>10$ simultaneously open flowers it is unlikely that emasculation resulted in strong pollen limitation. The following year, from 10 to 22 December 2004, we visited each of the 54 populations three times, and on each visit we emasculated, when possible (Appendix 2), one flower on one plant. In total we emasculated 154 flowers in 2003 and 135 flowers in 2004. We emasculated the flowers in their bud stage three to four days before anthesis. In both years, we marked one control flower on each plant that was in the same developmental stage as the emasculated flower. Two weeks later, we scored whether flowers had started to develop fruits. At that stage, developing fruits usually had a diameter between 1 and $2 \mathrm{~cm}$. We did not wait until complete fruit ripening because of the high chance that populations would be eradicated during weed-clearing operations in our study area.

Apart from the effect of emasculation on autonomous selfing, emasculation may affect fruit set through damage of flowers during anther removal and by changing attractiveness of flowers for pollen-collecting pollinators. The first potential side effect of emasculation seems to be of minor importance because anthers could easily be removed without damaging the flowers, and in a pilot experiment 13 out of 16 emasculated flowers set fruit with seed set as normal after handpollination. To test the effect of emasculation on visitation rates by honeybees, we simultaneously presented one emasculated and one intact flower mounted $40 \mathrm{~cm}$ apart at the end of a t-shaped stick to foraging insects in a $D$. stramonium population near Pietermaritzburg (population B22 in Appendix 2, December $27-$ 29, 2004). We conducted 12 presentations of fiveminute duration each and replaced the flowers for each presentation. The emasculated and non-emasculated flowers each received at least one visit for 11 of the 12 presentations. Although intact flowers tended to be visited more frequently than emasculated flowers (mean $\pm \mathrm{SE}=7.3 \pm 1.3$ vs $5.3 \pm 1.3$ pollinators), this effect was not significant $\left(t_{11}=1.86, \mathrm{p}=0.089\right)$.

\section{Outcrossing, seed production and germination in relation to population size}

To test the relationship between actual outcrossing rate and population size in D. stramonium, we used the natural anthocyanin color dimorphism which was present in 12 of the 19 populations of the first year (Appendix 1). Pollinators do not distinguish between the two color morphs of D. stramonium and visit them non-assortatively (Motten and Antonovics 1992, Stone 2000), and germination of seeds does not depend on the anthocyanin genotype of the embryo (Stone 2000). Therefore, unbiased population outcrossing rates can be determined by germinating the seed of white-flowered mother plants.

Depending on the number of white-flowered plants per population, we marked up to five flowers that had been open in the period between 30 November and 23 December 2003 on up to 11 white-flowered plants per population (49 plants and 204 flowers in total; Appendix 1). Because populations have a high chance of being eradicated by weed-clearing operations in our study area, we excavated all marked plants between 6 and 8 January 2004, and planted them in pots $(25 \mathrm{~cm}$ diameter, $22 \mathrm{~cm}$ height) in the Botanical Gardens of the Univ. of KwaZulu-Natal in Pietermaritzburg. To determine the frequency of homozygous and heterozygous purple-flowered plants, which is required for the calculation of outcrossing rates, we additionally transplanted up to ten purple-flowered plants from each population (69 plants in total; Appendix 1). On these purple-flowered plants, we enforced autogamous selffertilization by tying together the tip of the corolla tube of each of the flowers to prevent visitation by pollinators. Because in many cases (41 out of 69 plants), this procedure did not result in ripe fruits, we also included fruits from open-pollinated purple flowers. Any white offspring from purple-flowered mother plants would indicate that the mother plant is heterozygous at the anthocyanin locus.

We collected seeds from fruits after they had ripened. To stimulate germination, we soaked seeds in warm water for $24 \mathrm{~h}$ prior to sowing. On 11 and 25 January 2004, we sowed the seeds of each fruit separately in $15 \times 22 \times 6 \mathrm{~cm}$ trays filled with compost in a shadehouse in the Botanical Gardens of the Univ. of KwaZulu-Natal in Pietermaritzburg. In total, seeds of 206 and 170 fruits were sown from 49 white- and 69 purple-flowered maternal plants, respectively. Germination started within a week and continued for one year. Trays were watered each day. At least once a month, we counted and removed all red and green seedlings. After one year, on 23 January 2006, we finished the experiment.

For each of the 163 fruits ( $79.1 \%$ of total) of a white flowered plant with ten or more seedlings, we calculated the outcrossing rate by dividing the proportion of red offspring by the frequency of the anthocyanin allele in the population (Allard and Workman 1963, Motten and Antonovics 1992). We calculated the latter as the sum of the proportion of homozygous purple-flowered plants and half the proportion of heterozygous purpleflowered plants.

To test whether the number of seeds per fruit and germination rate of $D$. stramonium were affected by population size, we counted the number of seeds of naturally set fruit using a seed counting machine and counted the total number of seedlings per tray. 


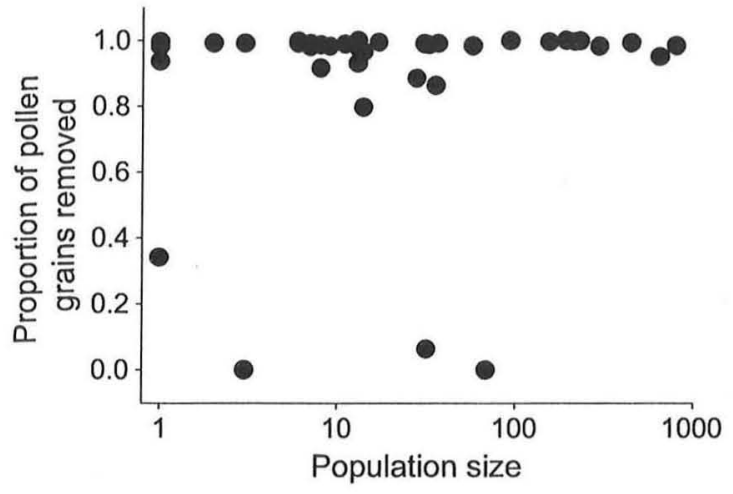

Fig. 1. Relationship between population size and proportion of pollen removed from anthers of Datura stramonium in its invasive range in South Africa.

Germination rate was calculated as the number of seedlings divided by the number of seeds per fruit.

\section{Data analyses}

To test whether pollen removal was affected by population size, we used simple regression of the proportion of removed pollen on the $\log 10$-transformed population size.

To test whether the binary data of fruit set in both years was affected by emasculation and population size, we used logistic regression using the statistical software GenStat (Lawes Agricultural Trust, IACR, Rothamsted, UK). We calculated ratios of changes in mean deviance (quasi F-values), which approximately follow the F-distribution (Payne et al. 2005). The $\log _{10^{-}}$ transformed geometric mean of population size over the experimental period was included as a covariate, emasculation treatment was included as a fixed factor, and population and plant nested within population were included as random factors.

To test whether seed production per fruit, germination rate and outcrossing rate were affected by population size, we used restricted maximum likelihood (REML) analyses of variance using the statistical software GenStat. The fixed model of the REML analyses included the $\log _{10}$-transformed geometric mean of population size over the experimental period as a covariate. We tested significance of the covariate with the Wald test statistic, which has an asymptotic chisquared distribution (Dobson 1990). The random model of the REML analyses included the factors population and plant nested within population. We tested the significance of random factors using the change in deviance after removing these terms from the model. The change in deviance is approximately chi-squared distributed (Littell et al. 1996). To achieve normality of the residuals, germination and outcrossing rates were square-root transformed prior to analyses.

To determine whether the effect of demographic stochasticity decreased with population size, we tested whether the deviation of observed from expected values of fruit set and pollen removal decreased with population size. This was done in a two-step procedure in which we first regressed the population means of fruit set in each treatment and year and pollen removal on population size, and calculated the residuals. We then regressed the absolute values of the residuals on population size. Because we had explicit expectations for the sign of the relationship between variation in trait values and population size, significance levels of regression coefficients were tested with one-tailed t-tests (Sokal and Rohlf 1995).

\section{Results}

\section{Pollen removal}

On average, there were $87.9 \%$ fewer pollen grains remaining in anthers of wilted flowers than in anthers of unopened control flowers. There was no significant relationship between the proportion of pollen removed from anthers and population size (standardized regression coefficient $=0.126, \mathrm{t}_{1,36}=0.761, \mathrm{p}=0.452$; Fig. 1).

Although variation in the proportion of pollen removed from anthers tended to be higher among small populations than among large populations (Fig. 1), the negative relationship between population size and the deviation of observed from expected pollen removal was not significant (standardized regression coefficient $=$ $-0.217, \mathrm{t}_{1,37}=-1.33$, one-tailed $\left.\mathrm{p}=0.096\right)$.

\section{Reproductive assurance}

Emasculation reduced fruit set significantly by on average $86.4 \%$ and $78.7 \%$ in the first and second year, respectively (Fig. 2, Table 1). Fruit set was not significantly affected by population size in both years (Fig. 2, Table 1) but in the first year the effect of the emasculation treatment on fruit set decreased with increasing population size (Fig. 1a, significant emasculation-by-size of population interaction in Table 1). This effect, however, was not only due to an increase in fruit set of emasculated flowers with increasing population size but also due to a decrease in fruit set of nonemasculated flowers with increasing population size. In the second year, the response of fruit set to the emasculation treatment was not significantly affected by population size (Fig. 2, Table 1). In both years, plants within populations differed significantly in fruit set, and in the second year populations differed 


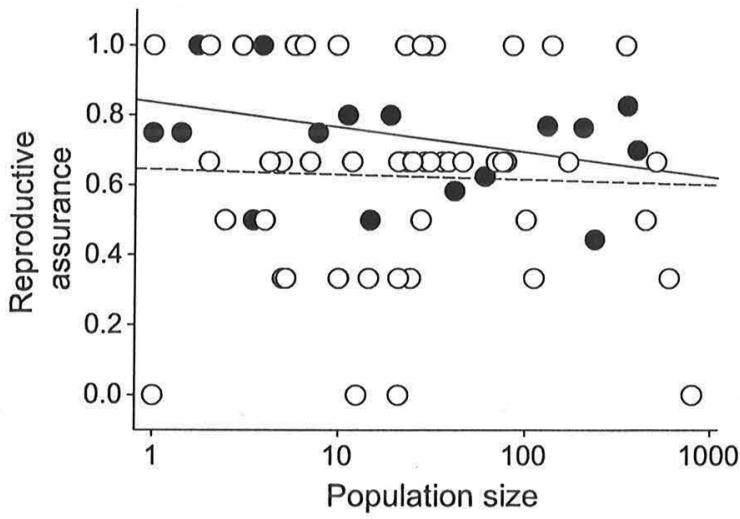

Fig. 2. Relationship between population size and reproductive assurance (i.e. the difference in fruit set between control and emasculated flowers of populations) in the experiments performed in 2003 (closed symbols, solid line) and 2004 (open symbol, dashed line) on Datura stramonium in its invasive range in South Africa.

significantly in the effect of the emasculation treatment on fruit set (Table 1).

Variation in fruit set of control flowers tended to be higher among small populations than among large populations in both the first and second year, indicating larger demographic stochasticity for small populations. This was reflected in a negative association between population size and the deviation of observed from expected fruit set of control flowers, which was significant in the second year (standardized regression coefficient $=-0.258, \mathrm{t}_{1,53}=-1.92$, one-tailed $\mathrm{p}=$ 0.030 ) but not in the first year (standardized regression coefficient $=-0.351, \mathrm{t}_{1,18}=-1.41$, one-tailed $\mathrm{p}=$ 0.091 ). For emasculated flowers the relationship between population size and the deviation of observed from expected fruit set was not significant in either year (first year: standardized regression coefficient $=0.075$, $t_{1,18}=0.28$, one-tailed $p=0.391$; second year: stan- dardized regression coefficient $=-0.102, \quad t_{1,53}=$ -0.74 , one-tailed $p=0.231$ ).

\section{Seed production per fruit and germination rate}

On average, plants produced $308.7(\mathrm{SE}=9.2)$ seeds per fruit, and $13.2 \%$ (upper $\mathrm{SE}=1.2$, lower $\mathrm{SE}=1.2$ ) of the seeds germinated within a year. Populations differed significantly in the number of seeds per fruit $\left(\chi_{1}=7.39\right.$, $\mathrm{p}=0.007)$ and germination rate $\left(\chi_{1}=8.11, \mathrm{p}=0.004\right)$ but this was not significantly related to the size of the populations (number of seeds per fruit: $\chi_{1}=0.00, p=$ 0.965; germination rate: $\chi_{1}=2.37, \mathrm{p}=0.123$; Fig. 3). Plants within populations differed significantly in number of seeds per fruit $\left(\chi_{1}=16.28, p<0.001\right)$ and germination rate $\left(\chi_{1}=48.92, \mathrm{p}<0.001\right)$.

\section{Outcrossing rates}

Outcrossing rates of individual plants of $D$. stramonium ranged from 0 to $100 \%$ but the average outcrossing rate per population was only $1.3 \%$. The outcrossing rate was not significantly affected by the size of the populations $\left(\chi_{1}=2.07, p=0.150\right.$; Fig. 4$)$, and also the remaining variation among populations was not significant $\left(\chi_{1}=\right.$ $0.02, p=0.888)$. Plants within populations, however, differed significantly in their outcrossing rate $\left(\chi_{1}=\right.$ 41.54, $\mathrm{p}<0.001$ ).

\section{Discussion}

\section{Absence of Allee effects}

Our results indicate that flower visitation by honeybees, fruit set, seed production, germination, reproductive assurance through self-fertilization, and outcrossing rate are generally independent of population size in $D$.

Table 1. Summaries of logistic regressions to test the effects of population size and emasculation on fruit set of Datura stramonium in its invasive range in South Africa in the experiments performed in 2003 (first year) and 2004 (second year).

\begin{tabular}{|c|c|c|c|c|c|c|}
\hline \multirow[t]{2}{*}{ Effect } & \multicolumn{3}{|c|}{ Fruit set in first year } & \multicolumn{3}{|c|}{ Fruit set in second year } \\
\hline & DF & Mean deviance & Quasi-F & DF & Mean deviance & Quasi-F \\
\hline Size of population & 1 & 0.3466 & 0.21 & 1 & 0.0455 & 0.03 \\
\hline Emasculation & 1 & 187.5668 & $1710.08^{* * * \dagger}$ & 1 & 115.6187 & $371.78^{* * *}$ \\
\hline Population & 17 & 1.6435 & 1.20 & 52 & 1.4194 & 0.71 \\
\hline Plant & 135 & 1.3707 & $12.49^{* * *}$ & 81 & 2.0115 & $29.38^{* * *}$ \\
\hline $\mathrm{E} \times \mathrm{S}$ & 1 & 6.5088 & $59.34^{* * *, \dagger}$ & 1 & 0.1245 & 0.40 \\
\hline$E \times P$ & 17 & 0.0000 & 0.00 & 52 & 0.3110 & $4.54^{* * *}$ \\
\hline Residual & 150 & 0.1097 & & 81 & 0.06846 & \\
\hline
\end{tabular}

*** $\mathrm{p}<0.001$

$\dagger$ Because the mean deviance for the emasculation-by-population interaction was 0 in the first year, the emasculation and emasculation-by-size of population interaction were tested against the residual 

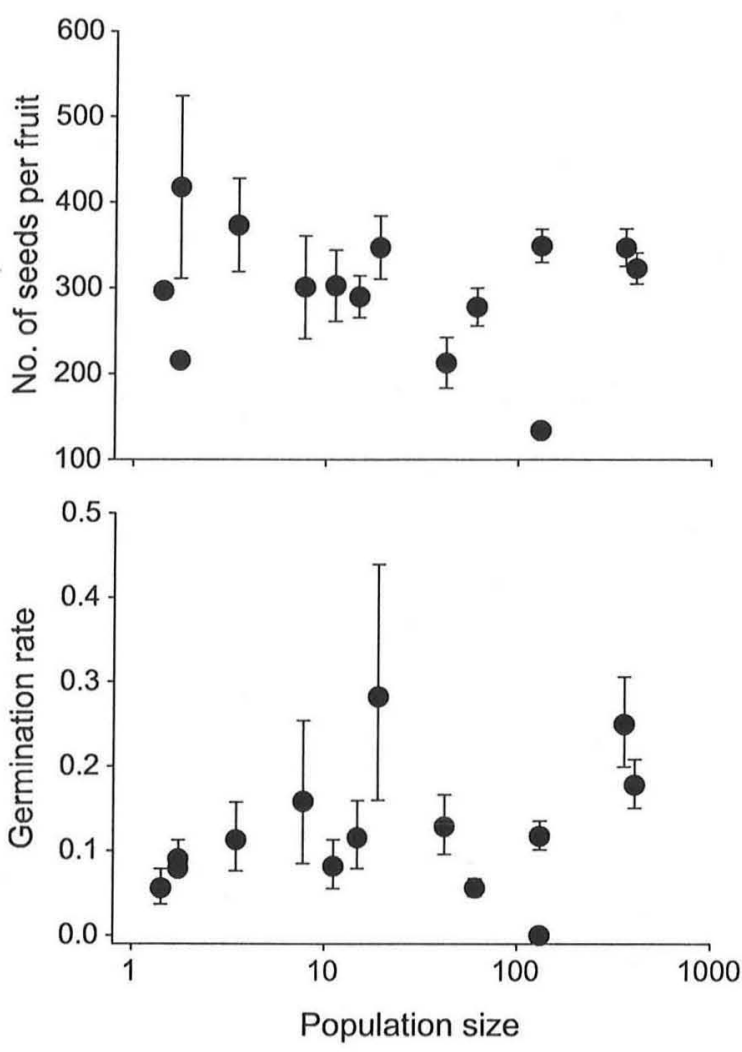

Fig. 3. Relationship between population size and number of seeds per fruit (a) and germination rate (b) of Datura stramonium in its invasive range in South Africa.

stramonium in its invasive range in South Africa. These results are consistent with the general expectation that Allee effects should be minimal or absent in highly invasive plants. At the same time, they do not sup-

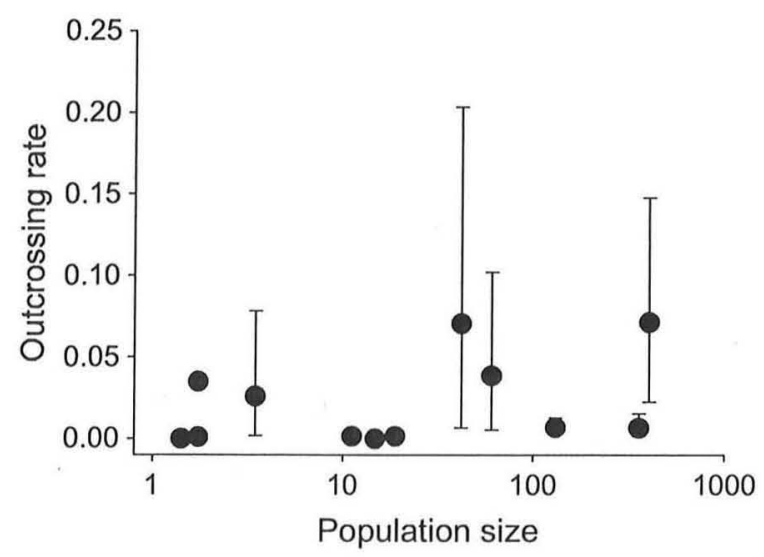

Fig. 4. Relationship between population size and outcrossing rate of Datura stramonium in its invasive range in South Africa. Data are population means + upper SE and - lower SE after back-transformation of square-root transformed data. port the specific hypothesis that the importance of reproductive assurance through self-fertilization would decrease with population size.

One possible explanation for the absence of Allee effects in our study could be that the size range of populations $(1-800)$ was not sufficiently large to detect Allee effects. This, however, is unlikely because strong Allee effects have even been found in studies with maximum population sizes $<100$ (Ward and Johnson 2005). Moreover, a recent meta-analysis of 45 studies by Leimu et al. (2006) showed that the strength and correlation between population size and fitness are independent of the size range of the studied populations. Therefore, we are confident that we should have detected Allee effects in D. stramonium if there had been any.

The low fruit set of emasculated flowers compared to intact flowers regardless of population size indicates that reproductive assurance by self-fertilization plays an important role in the reproduction of $D$. stramonium in its invasive range in South Africa. Although low fruit set in emasculated flowers could also reflect that these flowers are less attractive to pollinators, our pilot experiment (Material and methods) showed that honeybees also frequently visit emasculated flowers either because they do not notice in advance that the anthers are missing or because they try to reach the nectar. Although we do not have data on hawkmoth visitation, it is unlikely that this will be affected strongly by emasculation because hawkmoths forage for nectar and not for pollen. Even if pollinator visitation would be affected by the emasculation treatment, this effect should be independent of population size. Moreover, the selffertilization rates of intact flowers were also high and did not depend on population size. Therefore, we conclude that the importance of reproductive assurance through self-fertilization in D. stramonium is independent of population size in its invasive range in South Africa.

In a recent meta-analysis, van Kleunen and Johnson (2007) found that size of the invaded range of European species in the USA is associated with selfcompatibility. However, there have been hardly any studies that explicitly assessed outcrossing rates and reproductive assurance of alien invasive plants. We are aware of only one other study which has incorporated a test for reproductive assurance through self-fertilization in an invasive plant species. Schueller (2004) emasculated flowers of the partially self-fertilizing species Nicotiana glauca (Solanaceae) in island and mainland populations. Contrary to expectation, and to our results with $D$. stramonium, she found that in most cases emasculated flowers set as much fruit as intact flowers and that there were no significant differences between populations in the effect of this treatment on fruit set. This shows that not all self-compatible invasive species rely on self-fertilization in their exotic range. 
Although Allee effects could have important implications for the spread and management of introduced species, few other studies have empirically tested for Allee effects in invasive plants. In a previous study on the self-compatible, though not autogamous, shrub Senna didymobotrya, we also did not find evidence for Allee effects in its invasive range in South Africa (van Kleunen and Johnson 2005). On the other hand, Davis et al. (2004a, 2004b) found that plants of the largely self-incompatible grass Spartina alterniflora suffered from reduced seed set due to pollen limitation in lowdensity populations in its invasive range in western North America. A modeling study showed that this Allee effect is likely to reduce the speed of invasion of Spartina alterniflora (Taylor et al. 2004). Cappuccino (2004), however, did not find differences in pollinia removal in experimental low and high density patches of Vincetoxicum rossicum in its invasive range in Ontario. This, however, might be a consequence of the short distance among the patches in that garden experiment. Although more studies on Allee effects in invasive plants are clearly needed, our study and the few other ones suggest that while Allee effects play a role in invasions by self-incompatible plants, they tend to be absent, or present to only a small degree, in selfcompatible invasive plants.

\section{Demographic stochasticity}

Although we did not find effects of population size on the means of fitness components of $D$. stramonium, we found some indications that fruit set is more variable among small populations than among large populations. This effect was, however, only significant in the second year for fruit set of intact flowers. Similarly, in a previous study on the invasive shrub Senna didymobotrya, we found that variation in the size of offspring among populations declined with population size (van Kleunen and Johnson unpubl.). This indicates that demographic stochasticity may have a larger effect on plants in small than on the ones in large populations. This implies that even in the absence of Allee effects small populations of $D$. stramonium in its invasive range in South Africa may have a relatively higher extinction risk due to demographic stochasticity (Liebhold and Bascompte 2003).

\section{Pollination biology of Datura stramonium}

The large, scented, nocturnal flowers of $D$. stramonium with copious amounts of nectar suggest that hawkmoths are likely to be its primary pollinators. Although we have observed hawkmoths visiting the flowers, observations and the high levels of pollen removal from anthers of $D$. stramonium, which exceed levels of natural pollen shedding (Material and methods), indicate that plants of D. stramonium in its invasive range in South Africa are visited mainly by pollen-collecting honeybees. Similarly, Motten and Antonovics (1992) reported that flowers of $D$. stramonium in its invasive range in North America were visited during the evening by hawkmoths but during the late afternoons by honeybees that removed all pollen. Even though most flowers are visited by potential pollinators, the low fruit set of emasculated flowers and the low actual outcrossing rates in our study, as well as in the study by Motten and Antonovics (1992), indicate that visitation by honeybees and hawkmoths does not result in effective cross pollination of $D$. stramonium.

Our results show that the majority of offspring $(>98 \%)$ of D. stramonium in its invasive range in South Africa originate from self-fertilization. High selfing rates have also been found in the invasive range of D. stramonium in North America (Motten and Antonovics 1992, Motten and Stone 2000, Stone 2000). This could indicate that its flower visitors mainly assist in self-pollination in both South Africa and North America. Bagging experiments, however have shown that most flowers also set fruit when pollinators are excluded (Blakeslee and Avery 1917, Motten and Antonovics 1992, van Kleunen and Johnson unpubl.), and thus do not require the assistance of pollinators for self-fertilization. Therefore, we suggest that, although honeybees might cause some incidental outcrossing, they are most likely pollen robbers on $D$. stramonium (Thomson 2003) that do not leave much pollen for potential cross-pollination by hawkmoths. Similarly, Wilson and Thomson (1991) found that pollen-harvesting by introduced honeybees in North America reduced the quantities of pollen transferred by bumblebees to stigmas of Impatiens capensis.

Pollen removal by honeybees does not, however, prevent self-pollination. This could be because they actually facilitate self-pollination. Another possible explanation for this could be that self-pollination occurs in the flower buds before they are visited by honeybees. Observations have shown that anthers dehisce already $1-2$ days before flower opening and often result in pollen deposition on the stigma, which is then already receptive (Motten and Antonovics 1992, van Kleunen, pers. obs.). To test this possibility, we performed a small pilot experiment with 10 plants, and found the same high proportions of fruit set (0.8) for bagged flowers that were emasculated in the bud stage after anthers had dehisced as for bagged control flowers (Wilcoxonsigned-rank test: $Z=0.00, p=1.000)$. This suggests that early selfing may have evolved in $D$. stramonium in response to pollen robbing by honeybees.

Although the majority of flowers of $D$. stramonium produced seeds through self-fertilization only, some of the flowers produced seeds exclusively through 
outcrossing. Other studies on D. stramonium (Motten and Stone 2000) and other species (Ennos 1981, Dole 1992, van Kleunen and Ritland 2004), have shown that outcrossing rates in species with a mixed mating system are often positively associated with anther-stigma separation. Large anther-stigma separation may prevent early-acting self-fertilization and as a consequence still leave opportunity for cross-fertilization. The benefit of cross-fertilization over self-fertilization will depend on the chance of being cross-fertilized and the amount of inbreeding depression. The low fruit set of emasculated flowers indicates that the chances for cross-fertilization are relatively low for $D$. stramonium in its invasive range in South Africa.

A study by Núñez-Farfan et al. (1996) on $D$. stramonium in its presumed native range in Mexico showed that although artificial self-pollination resulted in fewer seeds per fruit than artificial cross-pollination, the quality of these seeds and the fitness of offspring did not suffer from inbreeding depression. Similarly, Stone and Motten (2002) found only weak inbreeding depression for D. stramonium in North Carolina. Moreover, the latter study only found inbreeding depression for plants of lineages with large antherstigma separation but not, and in some cases even negative inbreeding depression, for the ones of lineages with overlapping anthers and stigma. This suggests that inbreeding depression may have been purged from selfing lineages of $D$. stramonium. Overall, this indicates that the chance of cross-pollination and the degree of inbreeding depression in D. stramonium are likely to be too low to impose major selection for traits preventing early self-fertilization in this species.

\section{Conclusions}

Allee-effects and stochastic events could, in theory, prevent or slow down biological invasions (Taylor et al. 2004). Although Allee effects are likely to have prevented establishment and spread of some introduced species, successful invasive plants such as D. stramonium are likely to possess breeding systems that allow for reproduction in the absence of suitable mates or pollinators (Baker 1955, 1974). Furthermore, these breeding systems result in purging of deleterious alleles, such that genetic Allee effects are unlikely. Early-acting self-fertilization may even overrule potential outcrossing in the presence of suitable mates and pollinators. The absence of Allee effects in D. stramonium implies that eradication programs should not only target large populations but also small ones and even isolated single plants.

In $D$. stramonium, early-acting self-fertilization might act as reproductive assurance against pollen robbing honeybees rather than against the absence of suitable mates and pollinators in small populations.
Even though small populations of invasive species such as D. stramonium may not suffer from Allee effects, they may have a relatively high extinction risk as a consequence of demographic stochasticity. Although our hypothesis that reproductive assurance through selffertilization should vary with population size does not hold for $D$. stramonium, it would be worth testing whether it applies to invasive species with late-acting self-fertilization mechanisms.

Acknowledgements - We thank Sabrina Streif, Vanessa Pasqualetto, Chikondi Chanphunye, Ian Kippel and James Rodger for practical assistance, Marc Kéry for statistical advice, Rob Raguso for helpful comments on an earlier version of the manuscript and the DST Centre for Invasion Biology for funding the study.

\section{References}

Ågren, J. 1996. Population size, pollinator limitation and seed set in the self-incompatible herb Lythrum salicaria. - Ecology 77: 1779-1790.

Allard, R. W. and Workman, P. L. 1963. Population studies in predominantly self-pollinated species. IV. Seasonal fluctuations in estimated values of genetic parameters in lima bean populations. - Evolution 17: 470-480.

Baker, H. G. 1955. Self-compatibility and establishment after "long-distance" dispersal. - Evolution 9: 347-349.

Baker, H. G. 1974. The evolution of weeds. - Annu. Rev. Ecol. Syst. 7: 1-24.

Blakeslee, A. F. and Avery, B. T. 1917. Adzuki beans and Jimson weeds. - J. Hered. 8: 125-131.

Boukal, D. and Berec, L. 2002. Single-species models of the Allee effect: extinction boundaries, sex ratios and mate encounters. - J. Theor. Biol. 218: 375-394.

Cappuccino, N. 2004. Allee effect in an invasive alien plant, pale swallow-wort Vincetoxicum rossicum (Asclepiadaceae). - Oikos 106: 3-8.

Circosta, C. et al. 1985. Morphological characterization of the genus Datura: section Stramonium. - Int. J. Crude Drug Res. 23: 191-207.

Davis, H. G. et al. 2004a. An Allee effect at the front of a plant invasion: Spartina in a Pacific estuary. - J. Ecol. 92: 321-327.

Davis, H. G. et al. 2004b. Pollen limitation causes an Allee effect in a wind-pollinated invasive grass (Spartina alterniflora). - Proc. Natl Acad. Sci. USA 101: 1380413807.

Drake, J. M. and Lodge, D. M. 2006. Allee effects, propagule pressure and the probability of establishment: risk analysis for biological invasions. - Biol. Invas. 8: 365-375.

Dobson, A. J. 1990. An introduction to generalized linear models. - Chapman and Hall.

Dole, J. A. 1992. Reproductive assurance mechanisms in three taxa of the Mimulus guttatus complex (Scrophulariaceae). - Am. J. Bot. 79: 650-659. 
Eckert, C. G. and Schaefer, A. 1998. Does self-pollination provide reproductive assurance in Aquilegia canadensis (Ranunculaceae)? - Am. J. Bot. 85: 919-924.

Ennos, R. A. 1981. Quantitative studies on the mating system in two sympatric species of Ipomoea (Convovulaceae). - Genetica 57: 93-98.

Fischer, M. and Matthies, D. 1998. Effects of population size on performance in the rare plant Gentianella germanica. - J. Ecol. 86: 195-204.

Fischer, M. et al. 2000. Genetic Allee effects on performance, plasticity and developmental stability in a clonal plant. - Ecol. Lett. 3: 530-539.

Henderson, L. 2001. Alien weeds and invasive plants. - ARC-LNR.

Jiao, M. et al. 2002. Allozyme variation in Mexican species of Datura (Solanaceae). - Plant Syst. Evol. 232: 155-166.

Kéry, M. et al. 2003. Demographic stochasticity in population fragments of the declining distylous perennial Primula veris. - Basic Appl. Ecol. 4: 197-206.

Lande, R. 1993. Risks of population extinction from demographic and environmental stochasticity and random catastrophes. - Am. Nat. 142: 911-927.

Leimu, R. et al. 2006. How general are positive relationships between plant population size, fitness, and genetic variation? - J. Ecol. 94: 942-952.

Leung, B. et al. 2004. Predicting invasions: propagule pressure and the gravity of Allee effects. - Ecology 85: 1651-1660.

Lewis, M. A. and Kareiva, P. 1993. Allee dynamics and the spread of invading organisms. - Theor. Popul. Biol. 43: $141-158$.

Liebhold, A. and Bascompte, J. 2003. The Allee effect, stochastic dynamics and the eradication of alien species. - Ecol. Lett. 6: 133-140.

Littell, R. C. et al. 1996. SAS system for mixed models. - SAS Institute.

Motten, A. F. and Antonovics, J. 1992. Determinants of outcrossing rate in a predominantly self-fertilizing weed Datura stramonium (Solanaceae). - Am. J. Bot. 79: 419427.

Motten, A. F. and Stone, J. L. 2000. Heritability of stigma position and the effect of stigma-anther separation on outcrossing in a predominantly self-fertilizing weed, Datura stramonium (Solanaceae). - Am. J. Bot. 87: 339-347.

Núńez-Farfan, J. et al. 1996. Mating system consequences on resistance to herbivory and life history traits in Datura stramonium. - Am. J. Bot. 83: 1041-1049.

Oostermeijer, J. G. B. et al. 1994. Offspring fitness in relation to population size and genetic variation in the rare perennial plant species Gentiana pneumonanthe (Genianaceae). - Oecologia 97: 289-296.

Ouborg, N. J. et al. 2006. The rough edges of the conservation genetics paradigm for plants. - J. Ecol. 94: $1233-1248$.

Payne, R. W. et al. 2005. The guide to GenStat release 8. Part 2: statistics. - VSN International.

Raijmann, L. E. L. et al. 1994. Genetic variation and outcrossing rate in relation to population size in Gentiana pneumonanthe L. - Conserv. Biol. 8: 1014-1026.
Rambuda, T. D. and Johnson, S. D. 2004. Breeding systems of invasive alien plants in South Africa: does Baker's rule apply? - Div. Distrib. 10: 409-416.

Schueller, S. K. 2004. Self-pollination in island and mainland populations of the introduced hummingbird-pollinated plant Nicotiana glauca (Solanaceae). - Am. J. Bot. 91: 672-681.

Silander, J. A. 1978. Density-dependent control of reproductive success in Cassia biflora. - Biotropica 10: 292-296.

Sokal, R. R. and Rohlf, F. J. 1995. Biometry. - W. H. Freeman and Company.

Stebbins, G. L. 1957. Self fertilization and population variability in the higher plants. - Am. Nat. 91: 337-354.

Stephens, P. A. et al. 1999. What is the Allee effect? - Oikos 87: $185-190$.

Stone, J. L. 2000. Does anthocyanin affect outcrossing rates in Datura stramonium (Solanaceae)? - Am. J. Bot. 87: 348354.

Stone, J. L. and Motten, A. F. 2002. Anther-stigma separation is associated with inbreeding depression in Datura stramonium, a predominantly self-fertilizing annual. - Evolution 56: 2187-2195.

Taylor, C. M. and Hastings, A. 2004. Finding optimal control strategies for invasive species: a density-structured model for Spartina alterniflora. - J. Appl. Ecol. 41: 1049-1057.

Taylor, C. M. and Hastings, A. 2005. Allee effects in biological invasions. - Ecol. Lett. 8: 895-908.

Taylor, C. M. et al. 2004. Consequences of an Allee effect on the invasion of a Pacific estuary by Spartina alterniflora. - Ecology 85: 3254-3266.

Thomson, J. 2003. When is it mutualism? - Am. Nat. 162: S1-S9.

Tobin, P. C. et al. 2007. Invasion speed is affected by geographical variation in the strength of Allee effects. - Ecol. Lett. 10: 36-43.

van Kleunen, M. and Ritland, K. 2004. Predicting evolution of floral traits associated with mating system in a natural plant population. - J. Evol. Biol. 17: 1389-1399.

van Kleunen, M. and Johnson, S. D. 2005. Testing for ecological and genetic Allee effects in the invasive shrub Senna didymobotrya (Fabaceae). - Am. J. Bot. 92: 11241130.

van Kleunen, M. and Johnson, S. D. 2007. Effects of Selfcompatibility on the distribution range of invasive European plants in North America. - Conserv. Biol., in press.

Veit, R. R. and Lewis, M. A. 1996. Dispersal, population growth, and the Allee effect: dynamics of the house finch invasion of eastern North America. - Am. Nat. 148: 255-274.

Ward, M. and Johnson, S. D. 2005. Pollen limitation and demographic structure in small fragmented populations of Brunsvigia radulosa (Amaryllidaceae). - Oikos 108: 253262.

Wilson, P. and Thomson, J. D. 1991. Heterogeneity among floral visitors leads to discordance between removal and deposition of pollen. - Ecology 72: 1503-1507. 
Appendix 1. Geographical coordinates, size and number of replicate plants used in experiments on reproductive assurance and outcrossing rate for the 20 populations of Datura stramonium used in 2003 (first year) in its invasive range in South Africa. For the experiment on outcrossing rate, the column 'white' gives the number of white-flowered plants from which outcrossing rates were estimated and the column 'purple' gives the number of purple-flowered plants from which the proportions of heterozygous and homozygous purpleflowered plants were estimated.

\begin{tabular}{|c|c|c|c|c|c|c|c|c|c|}
\hline \multirow[t]{2}{*}{ Population } & \multirow[t]{2}{*}{ Latitude (S) } & \multirow[t]{2}{*}{ Longitude $(\mathrm{E})$} & \multirow[t]{2}{*}{$\begin{array}{l}\text { Altitude } \\
\text { [m a.s.l.] }\end{array}$} & \multirow[t]{2}{*}{$\begin{array}{l}\text { Population } \\
\text { size at start }\end{array}$} & \multirow[t]{2}{*}{$\begin{array}{l}\text { Population } \\
\text { size at end }\end{array}$} & \multirow[t]{2}{*}{$\begin{array}{l}\text { Geometric mean } \\
\text { of population size }\end{array}$} & \multirow{2}{*}{$\begin{array}{c}\text { No. of } \\
\text { emasculated } \\
\text { flowers in } \\
\text { reproductive-assurance } \\
\text { experiment }\end{array}$} & \multicolumn{2}{|c|}{$\begin{array}{l}\text { No. of plants in } \\
\text { outcrossing } \\
\text { experiment }\end{array}$} \\
\hline & & & & & & & & White & Purple \\
\hline A14 & $29^{\circ} 37^{\prime} 61^{\prime \prime}$ & $30^{\circ} 24^{\prime} 16^{\prime \prime}$ & 673 & 1 & 1 & 1 & 4 & - & - \\
\hline A15 & $29^{\circ} 46^{\prime} 37^{\prime \prime}$ & $30^{\circ} 21^{\prime} 62^{\prime \prime}$ & 760 & 1 & 1 & 1 & 4 & - & - \\
\hline $\mathrm{A} 02$ & $29^{\circ} 34^{\prime} 03^{\prime \prime}$ & $30^{\circ} 26^{\prime} 62^{\prime \prime}$ & 824 & 1 & 2 & 1.4 & 4 & 1 & 1 \\
\hline A20 & $30^{\circ} 09^{\prime} 95^{\prime \prime}$ & $30^{\circ} 06^{\prime} 66^{\prime \prime}$ & 1116 & 1 & 2 & 1.4 & 4 & - & - \\
\hline A05 & $29^{\circ} 41^{\prime} 74^{\prime \prime}$ & $30^{\circ} 24^{\prime} 41^{\prime \prime}$ & 814 & 3 & 1 & 1.7 & 1 & 2 & 0 \\
\hline A22 & $29^{\circ} 39^{\prime} 31^{\prime \prime}$ & $30^{\circ} 22^{\prime} 91^{\prime \prime}$ & 770 & 3 & 1 & 1.7 & - & 1 & 0 \\
\hline A04 & $29^{\circ} 34^{\prime} 36^{\prime \prime}$ & $30^{\circ} 25^{\prime} 94^{\prime \prime}$ & 778 & 3 & 4 & 3.5 & 2 & 3 & 2 \\
\hline A12 & $29^{\circ} 41^{\prime} 98^{\prime \prime}$ & $30^{\circ} 29^{\prime} 84^{\prime \prime}$ & 772 & 5 & 3 & 3.9 & 2 & - & - \\
\hline A21 & $29^{\circ} 48^{\prime} 75^{\prime \prime}$ & $30^{\circ} 20^{\prime} 56^{\prime \prime}$ & 839 & 7 & 5 & 5.9 & 3 & - & - \\
\hline A10 & $29^{\circ} 27^{\prime} 65^{\prime \prime}$ & $30^{\circ} 08^{\prime} 73^{\prime \prime}$ & 1098 & 10 & 6 & 7.7 & 4 & - & - \\
\hline A09 & $29^{\circ} 29^{\prime} 80^{\prime \prime}$ & $30^{\circ} 12^{\prime} 55^{\prime \prime}$ & 1067 & 9 & 14 & 11.2 & 5 & 3 & 4 \\
\hline A16 & $29^{\circ} 52^{\prime} 56^{\prime \prime}$ & $30^{\circ} 16^{\prime} 95^{\prime \prime}$ & 860 & 20 & 11 & 14.8 & 4 & 3 & 4 \\
\hline A11 & $29^{\circ} 34^{\prime} 95^{\prime \prime}$ & $30^{\circ} 22^{\prime} 51^{\prime \prime}$ & 647 & 9 & 40 & 19 & 5 & 3 & 4 \\
\hline $\mathrm{A} 07$ & $29^{\circ} 43^{\prime} 73^{\prime \prime}$ & $30^{\circ} 33^{\prime} 00^{\prime \prime}$ & 765 & 37 & 48 & 42.1 & 6 & 3 & 8 \\
\hline $\mathrm{A} 03$ & $29^{\circ} 30^{\prime} 47^{\prime \prime}$ & $30^{\circ} 29^{\prime} 16^{\prime \prime}$ & 723 & 56 & 66 & 60.8 & 8 & 6 & 10 \\
\hline A17 & $29^{\circ} 53^{\prime} 12^{\prime \prime}$ & $30^{\circ} 17^{\prime} 27^{\prime \prime}$ & 852 & 140 & 123 & 131.2 & 13 & 5 & 11 \\
\hline A19 & $30^{\circ} 08^{\prime} 61^{\prime \prime}$ & $30^{\circ} 04^{\prime} 43^{\prime \prime}$ & 944 & 121 & 351 & 206.1 & 17 & - & - \\
\hline A18 & $29^{\circ} 54^{\prime} 30^{\prime \prime}$ & $30^{\circ} 17^{\prime} 61^{\prime \prime}$ & 874 & 300 & 190 & 238.7 & 9 & - & - \\
\hline A08 & $29^{\circ} 43^{\prime} 77^{\prime \prime}$ & $30^{\circ} 35^{\prime} 00^{\prime \prime}$ & 741 & 370 & 348 & 358.8 & 29 & 7 & 8 \\
\hline A01 & $29^{\circ} 39^{\prime} 92^{\prime \prime}$ & $30^{\circ} 24^{\prime} 86^{\prime \prime}$ & 767 & 260 & 635 & 406.3 & 30 & 9 & 13 \\
\hline
\end{tabular}


Appendix 2. Geographical coordinates, size and number of replicate plants used in the experiments on reproductive assurance and pollen loss of the 55 populations of Datura stramonium used in 2004 (second year) in its invasive range in South Africa. Six of the populations had also been included in the first year.

\begin{tabular}{|c|c|c|c|c|c|c|c|c|}
\hline Population & Latitude (S) & Longitude (E) & $\begin{array}{l}\text { Altitude } \\
\text { [m asl] }\end{array}$ & $\begin{array}{l}\text { Population } \\
\text { size at start }\end{array}$ & $\begin{array}{l}\text { Population } \\
\text { size at end }\end{array}$ & $\begin{array}{l}\text { Geometric mean } \\
\text { of population size }\end{array}$ & $\begin{array}{l}\text { No. of } \\
\text { emasculated } \\
\text { flowers in } \\
\text { reproductive } \\
\text { assurance } \\
\text { experiment }\end{array}$ & $\begin{array}{l}\text { Pollen-loss } \\
\text { experiment }\end{array}$ \\
\hline
\end{tabular}

\begin{tabular}{|c|c|c|c|c|c|c|c|c|}
\hline & & & & & & \\
\hline B02 & $29^{\circ} 39^{\prime} 09^{\prime \prime}$ & $30^{\circ} 22^{\prime} 80^{\prime \prime}$ & 756 & 1 & 1 & 1 & 1 & 1 \\
\hline B38 & $29^{\circ} 41^{\prime} 04^{\prime \prime}$ & $30^{\circ} 23^{\prime} 96^{\prime \prime}$ & 784 & 1 & 1 & 1 & 1 & - \\
\hline B39 & $29^{\circ} 41^{\prime} 13^{\prime \prime}$ & $30^{\circ} 23^{\prime} 99^{\prime \prime}$ & 792 & 1 & 1 & 1 & 1 & - \\
\hline B42 & $29^{\circ} 42^{\prime} 07^{\prime \prime}$ & $30^{\circ} 24^{\prime} 76^{\prime \prime}$ & 814 & 1 & 1 & 1 & 1 & - \\
\hline B44 & $29^{\circ} 40^{\prime} 18^{\prime \prime}$ & $30^{\circ} 26^{\prime} 76^{\prime \prime}$ & 713 & 1 & 1 & 1 & 1 & - \\
\hline B50 & $29^{\circ} 43^{\prime} 74^{\prime \prime}$ & $30^{\circ} 34^{\prime} 99^{\prime \prime}$ & 744 & 1 & 1 & 1 & 3 & 1 \\
\hline B53 & $29^{\circ} 43^{\prime} 90^{\prime \prime}$ & $30^{\circ} 35^{\prime} 79^{\prime \prime}$ & 747 & 1 & 1 & 1 & 3 & 1 \\
\hline B56 & $30^{\circ} 09^{\prime} 32^{\prime \prime}$ & $30^{\circ} 03^{\prime} 92^{\prime \prime}$ & 1006 & 2 & 2 & 2 & 1 & - \\
\hline B29 & $29^{\circ} 21^{\prime} 77^{\prime \prime}$ & $30^{\circ} 15^{\prime} 61^{\prime \prime}$ & 1091 & 2 & 2 & 2 & 3 & 1 \\
\hline B07 & $30^{\circ} 08^{\prime} 61^{\prime \prime}$ & $30^{\circ} 04^{\prime} 43^{\prime \prime}$ & 944 & 2 & 3 & 2.4 & 2 & - \\
\hline $\mathrm{B} 15=\mathrm{A} 22$ & $29^{\circ} 39^{\prime} 31^{\prime \prime}$ & $30^{\circ} 22^{\prime} 91^{\prime \prime}$ & 770 & 3 & 3 & 3 & 1 & 1 \\
\hline B09 & $30^{\circ} 09^{\prime} 40^{\prime \prime}$ & $30^{\circ} 03^{\prime} 91^{\prime \prime}$ & 1011 & 4 & 4 & 4 & 2 & - \\
\hline B59 & $29^{\circ} 32^{\prime} 55^{\prime \prime}$ & $30^{\circ} 28^{\prime} 73^{\prime \prime}$ & 737 & 2 & 9 & 4.2 & 3 & - \\
\hline B26 & $29^{\circ} 31^{\prime} 04^{\prime \prime}$ & $30^{\circ} 13^{\prime} 93^{\prime \prime}$ & 1019 & 4 & 6 & 4.9 & 3 & 1 \\
\hline $\mathrm{B} 21=\mathrm{A} 04$ & $29^{\circ} 34^{\prime} 36^{\prime \prime}$ & $30^{\circ} 25^{\prime} 94^{\prime \prime}$ & 778 & 5 & 5 & 5 & 3 & 1 \\
\hline B30 & $29^{\circ} 25^{\prime} 54^{\prime \prime}$ & $30^{\circ} 14^{\prime} 49^{\prime \prime}$ & 1142 & 3 & 9 & 5.2 & 3 & 1 \\
\hline B34 & $29^{\circ} 29^{\prime} 59^{\prime \prime}$ & $30^{\circ} 12^{\prime} 19^{\prime \prime}$ & 1035 & 3 & 11 & 5.7 & 3 & 1 \\
\hline B55 & $29^{\circ} 36^{\prime} 74^{\prime \prime}$ & $30^{\circ} 23^{\prime} 26^{\prime \prime}$ & 604 & 7 & 6 & 6.5 & 3 & 1 \\
\hline B24 & $29^{\circ} 30^{\prime} 84^{\prime \prime}$ & $30^{\circ} 29^{\prime} 04^{\prime \prime}$ & 643 & 7 & 7 & 7 & 3 & 1 \\
\hline $\mathrm{B} 61$ & $29^{\circ} 41^{\prime} 26^{\prime \prime}$ & $30^{\circ} 24^{\prime} 09^{\prime \prime}$ & 796 & 7 & 7 & 7 & - & 1 \\
\hline B49 & $29^{\circ} 43^{\prime} 95^{\prime \prime}$ & $30^{\circ} 34^{\prime} 86^{\prime \prime}$ & 752 & 8 & 12 & 9.8 & 3 & 1 \\
\hline B37 & $29^{\circ} 38^{\prime} 73^{\prime \prime}$ & $30^{\circ} 24^{\prime} 84^{\prime \prime}$ & 715 & 10 & 10 & 10 & 3 & 1 \\
\hline B35 & $29^{\circ} 28^{\prime} 99^{\prime \prime}$ & $30^{\circ} 10^{\prime} 71^{\prime \prime}$ & 1098 & 10 & 14 & 11.8 & 3 & - \\
\hline B14 & $30^{\circ} 46^{\prime} 19^{\prime \prime}$ & $30^{\circ} 21^{\prime} 77^{\prime \prime}$ & 777 & 12 & 13 & 12.5 & 3 & 1 \\
\hline B17 & $29^{\circ} 39^{\prime} 94^{\prime \prime}$ & $30^{\circ} 24^{\prime} 86^{\prime \prime}$ & 765 & 15 & 14 & 14.5 & 3 & 1 \\
\hline B33 & $29^{\circ} 30^{\prime} 07^{\prime \prime}$ & $30^{\circ} 12^{\prime} 90^{\prime \prime}$ & 648 & 21 & 21 & 21 & 3 & 1 \\
\hline B43 & $29^{\circ} 41^{\prime} 79^{\prime \prime}$ & $30^{\circ} 25^{\prime} 17^{\prime \prime}$ & 815 & 21 & 21 & 21 & 1 & 1 \\
\hline B47 & $29^{\circ} 43^{\prime} 68^{\prime \prime}$ & $30^{\circ} 30^{\prime} 86^{\prime \prime}$ & 809 & 21 & 21 & 21 & 3 & 1 \\
\hline B40 & $29^{\circ} 41^{\prime} 39^{\prime \prime}$ & $30^{\circ} 24^{\prime} 19^{\prime \prime}$ & 800 & 32 & 16 & 22.6 & 2 & $i$ \\
\hline B31 & $29^{\circ} 28^{\prime} 20^{\prime \prime}$ & $30^{\circ} 14^{\prime} 50^{\prime \prime}$ & 1028 & 24 & 23 & 23.5 & 3 & 1 \\
\hline B16 & $29^{\circ} 39^{\prime} 78^{\prime \prime}$ & $30^{\circ} 25^{\prime} 15^{\prime \prime}$ & 747 & 18 & 33 & 24.4 & 3 & 1 \\
\hline B45 & $29^{\circ} 42^{\prime} 00^{\prime \prime}$ & $30^{\circ} 29^{\prime} 42^{\prime \prime}$ & 781 & 24 & 26 & 25 & 3 & 1 \\
\hline B12 & $30^{\circ} 06^{\prime} 18^{\prime \prime}$ & $30^{\circ} 07^{\prime} 98^{\prime \prime}$ & 924 & 11 & 70 & 27.7 & 2 & - \\
\hline B41 & $29^{\circ} 41^{\prime} 84^{\prime \prime}$ & $30^{\circ} 24^{\prime} 47^{\prime \prime}$ & 816 & 31 & 25 & 27.8 & 3 & 1 \\
\hline B01 & $29^{\circ} 37^{\prime} 57^{\prime \prime}$ & $30^{\circ} 25^{\prime} 48^{\prime \prime}$ & 692 & 29 & 29 & 29 & 3 & - \\
\hline B10 & $30^{\circ} 08^{\prime} 79^{\prime \prime}$ & $30^{\circ} 04^{\prime} 17^{\prime \prime}$ & 958 & 23 & 40 & 30.3 & 1 & _ \\
\hline B28 & $29^{\circ} 21^{\prime} 65^{\prime \prime}$ & $30^{\circ} 15^{\prime} 63^{\prime \prime}$ & 1066 & 32 & 30 & 31 & 3 & 1 \\
\hline B23 & $29^{\circ} 31^{\prime} 19^{\prime \prime}$ & $30^{\circ} 30^{\prime} 04^{\prime \prime}$ & 595 & 33 & 32 & 32.5 & 3 & 1 \\
\hline $\mathrm{B} 04=\mathrm{A} 17$ & $29^{\circ} 53^{\prime} 12^{\prime \prime}$ & $30^{\circ} 17^{\prime} 27^{\prime \prime}$ & 852 & 36 & 36 & 36 & 3 & 1 \\
\hline
\end{tabular}


Appendix 2 (Continued)

\begin{tabular}{|c|c|c|c|c|c|c|c|c|}
\hline Population & Latitude (S) & Longitude (E) & $\begin{array}{l}\text { Altitude } \\
\text { [m asl] }\end{array}$ & $\begin{array}{l}\text { Population } \\
\text { size at start }\end{array}$ & $\begin{array}{l}\text { Population } \\
\text { size at end }\end{array}$ & $\begin{array}{l}\text { Geometric mean } \\
\text { of population size }\end{array}$ & $\begin{array}{l}\text { No. of } \\
\text { emasculated } \\
\text { flowers in } \\
\text { reproductive } \\
\text { assurance } \\
\text { experiment }\end{array}$ & $\begin{array}{l}\text { Pollen-loss } \\
\text { experiment }\end{array}$ \\
\hline $\mathrm{B} 05=\mathrm{A} 18$ & $29^{\circ} 54^{\prime} 30^{\prime \prime}$ & $30^{\circ} 17^{\prime} 61^{\prime \prime}$ & 874 & 39 & 39 & 39 & 3 & - \\
\hline B08 & $30^{\circ} 08^{\prime} 64^{\prime \prime}$ & $30^{\circ} 04^{\prime} 33^{\prime \prime}$ & 930 & 37 & 58 & 46.3 & 3 & - \\
\hline B20 & $29^{\circ} 35^{\prime} 03^{\prime \prime}$ & $30^{\circ} 24^{\prime} 98^{\prime \prime}$ & 669 & 77 & 63 & 69.6 & 3 & 1 \\
\hline B51 & $29^{\circ} 43^{\prime} 79^{\prime \prime}$ & $30^{\circ} 35^{\prime} 17^{\prime \prime}$ & 758 & 46 & 124 & 75.5 & 3 & 1 \\
\hline B48 & $29^{\circ} 43^{\prime} 73^{\prime \prime}$ & $30^{\circ} 32^{\prime} 51^{\prime \prime}$ & 766 & 65 & 95 & 78.6 & 3 & - \\
\hline B46 & $29^{\circ} 43^{\prime} 55^{\prime \prime}$ & $30^{\circ} 30^{\prime} 24^{\prime \prime}$ & 797 & 80 & 78 & 79 & 3 & 1 \\
\hline B58 & $29^{\circ} 45^{\prime} 37^{\prime \prime}$ & $30^{\circ} 21^{\prime} 28^{\prime \prime}$ & 788 & 72 & 101 & 85.2 & 2 & 1 \\
\hline B54 & $29^{\circ} 37^{\prime} 10^{\prime \prime}$ & $30^{\circ} 22^{\prime} 70^{\prime \prime}$ & 609 & 68 & 150 & 101 & 2 & 1 \\
\hline $\mathrm{B} 25=\mathrm{A} 03$ & $29^{\circ} 30^{\prime} 47^{\prime \prime}$ & $30^{\circ} 29^{\prime} 16^{\prime \prime}$ & 723 & 70 & 178 & 111.6 & 3 & 1 \\
\hline B36 & $29^{\circ} 28^{\prime} 53^{\prime \prime}$ & $30^{\circ} 12^{\prime} 34^{\prime \prime}$ & 1067 & 95 & 202 & 138.5 & 3 & 1 \\
\hline B22 & $29^{\circ} 32^{\prime} 35^{\prime \prime}$ & $30^{\circ} 29^{\prime} 36^{\prime \prime}$ & 640 & 126 & 231 & 170.6 & 3 & 1 \\
\hline B11 & $30^{\circ} 08^{\prime} 57^{\prime \prime}$ & $30^{\circ} 04^{\prime} 44^{\prime \prime}$ & 959 & 350 & 350 & 350 & 1 & - \\
\hline B57 & $29^{\circ} 50^{\prime} 57^{\prime \prime}$ & $30^{\circ} 18^{\prime} 40^{\prime \prime}$ & 897 & 450 & 450 & 450 & 2 & 1 \\
\hline B27 & $29^{\circ} 28^{\prime} 47^{\prime \prime}$ & $30^{\circ} 14^{\prime} 23^{\prime \prime}$ & 1011 & 402 & 652 & 512 & 3 & 1 \\
\hline $\mathrm{B} 60$ & $29^{\circ} 32^{\prime} 13^{\prime \prime}$ & $30^{\circ} 29^{\prime} 29^{\prime \prime}$ & 665 & 603 & 603 & 603 & 3 & - \\
\hline $\mathrm{B} 18=\mathrm{A} 01$ & $29^{\circ} 39^{\prime} 92^{\prime \prime}$ & $30^{\circ} 24^{\prime} 86^{\prime \prime}$ & 767 & 800 & 800 & 800 & 3 & 1 \\
\hline
\end{tabular}

